\title{
Predictors of typical atrial flutter recurrence following radiofrequency ablation of cavotricuspid isthmus using extrenally irrigated-tip catheters
}

\author{
Nebojša Mujovići, ${ }^{1,2}$, Milan Marinković ${ }^{1}$, Nebojša Markovići ${ }^{1}$, Tatjana S. Potpara ${ }^{1,2}$ \\ ${ }^{1}$ Cardiology Clinic, Clinical Center of Serbia, Višegradska 26, Belgrade, Serbia; ${ }^{2}$ School of Medicine, University of Belgrade, \\ Dr Subotića 8, Belgrade, Serbia
}

Abstract

Introduction: Identification of fisk factors for the recurrence of atrial flutter (R-AFL) after radiofrequency (RF) catheter-ablation (CA) may provide better patient selection for invasive treatment and optimal postprocedural treatment. We investigated the incidence, time frame of R-AFLs and predictors of R-AFLs after CA.

Methods: We retrospectively analysed the patients undergoing externally irrigated RF-CA (30-50W) for typical AFL and with end-point of isthmus-block during 7-year period. The patient follow-up visits consisting of ECG and $24 \mathrm{~h}$-Holter were scheduled at 6 -month intervals after the procedure.

Results: Total of 248 patients (mean age $57.4 \pm 11.6$ years, $72.6 \%$ male) underwent 303 RF-CAs. The procedure was repated in 45 patients (1-4 times per patient). Primary CA success rate was $87 \%$. During the follow-up of $17.6 \pm 14.7$ months, $22.6 \%$ and $5.7 \%$ of patients had R-AFL following the first and the last procedure, respectively. The mean time from CA to RAFL was $8.1 \pm 6.4$ months ( 1 day to 33 months). The majority of R-AFL (72.7\%) occurred in the first year post procedure. On univariate analysis, R-AFL was significantly associated with age, P-wave amplitude, hyperlipidemia, left atrial diameter, fluoroscopy time, achievement of isthmus-block, use of analgosedation and operator's expirience. Multivariable analysis demonstrated that age (HR: 0.95), stable isthmus-block (HR: 0.22) and hyperlipidemia (HR: 2.00) were independent predictors of R-AFL.

Conclusion: R-AFL rate after final RF-CA was about $6 \%$, but procedure was repeated in every fifth patient. R-AFL mostly occurred during the first postprocedural year. The R-AFL predictors after RFCA were younger age, hyperlipidemia and incomplete isthmus ablation.

Key Words atrial flutter; catheter-ablation; cavo-tricuspid isthmus; recurrence after ablation

\section{Introduction}

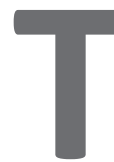

ypical atrial flutter (AFL) is the second most common arrhythmia after atrial fibrillation (AF) and is associated with increased mortality rate and increased risk of thromboembolism or heart failure. ${ }^{1}$

Due to its high efficacy and safety, percutaneous catheter-ablation (CA), has become the first treatment option for patients with typical AFL. ${ }^{2}$ Ablation of typical AFL using radiofrequency (RF) current is based on the creation of transmural and complete necrotic lesion over the entire isthmus between the base of the right ventricle and the inferior vena cava. ${ }^{3}$ The application of advanced technologies in recent years, such as externally irrigated-tip catheters, has shortened the procedure and reduced the AFL recurrence. ${ }^{4}$

Identification of time frame of AFL recurrences as well as potential predictors of AFL recurrence after RF-
CA could be clinically useful for identifying the patients who require multiple procedures and the continuation of antiarrhythmic drug therapy after the ablation. We analyzed the incidence and predictors of AFL recurrence after a typical AFL ablation in a set of more than 300 consecutive procedures, starting from the introduction of irrigation RF technology in our center.

\section{Methods}

This primary clinical observational study included all adult patients who underwent RF-CA of typical AFL using the externally irrigated-tip catheters in the period from January 2007 to December 2013 in Clinical Centre of Serbia. Data were collected from patients' histories, the electrophysiology (EP) laboratory electronic database and the protocols fulfilled during the clinical follow-up after the procedure. 
Table 1. Baseline patients' characteristics at first procedure

\begin{tabular}{|c|c|}
\hline & $\begin{array}{l}\text { Patients referred to AFL } \\
\text { ablation }(n=248)\end{array}$ \\
\hline Age (years) & $57.4 \pm 11.6$ \\
\hline Male gender & $180(72.6 \%)$ \\
\hline $\mathrm{BMI}\left(\mathrm{kg} / \mathrm{m}^{2}\right)$ & $27.5 \pm 4.4$ \\
\hline History of AFL (years) & $5.0 \pm 3.9$ \\
\hline Paroxysmal AFL & $85(34.3 \%)$ \\
\hline Persistent AFL & $163(65.7 \%)$ \\
\hline AF before procedure & $110(44.4 \%)$ \\
\hline LV ejection fraction (\%) & $53.6 \pm 13.5$ \\
\hline Left atrial diameter (mm) & $42.8 \pm 5.9$ \\
\hline Heart failure & $89(35.9 \%)$ \\
\hline Structural heart disease & $139(56.0 \%)$ \\
\hline Dilated cardiomyopathy & $96(38.7 \%)$ \\
\hline Coronary artery disease & $50(20.2 \%)$ \\
\hline Congenital heart disease & $25(10.1 \%)$ \\
\hline Valvular heart disease & $20(8.1 \%)$ \\
\hline Comorbidities & $193(77.8 \%)$ \\
\hline Systemic hypertension & $145(58.4 \%)$ \\
\hline Hyperlipoproteinemia & $106(42.7 \%)$ \\
\hline Diabetes mellitus & $33(13.3 \%)$ \\
\hline Chronic renal failure & $24(9.7 \%)$ \\
\hline $\begin{array}{l}\text { Chronic obstructive pulmonary } \\
\text { disease }\end{array}$ & $14(5.6 \%)$ \\
\hline Stroke or TIA & $8(3.2 \%)$ \\
\hline $\mathrm{CHADS}_{2}$ score $(\mathrm{n})$ & $1.2 \pm 1.0$ \\
\hline AADs use before ablation & $242(97.6 \%)$ \\
\hline Number of AADs per patient (n) & $2.5 \pm 1.2$ \\
\hline Amiodaron & $189(76.2 \%)$ \\
\hline
\end{tabular}

Data presented as mean \pm SD or numbers with percentages.

$A F L=$ atrial flutter; $B M I=b o d y$ mass index; $A F=$ atrial fibrillation; $L V=l e f t$ ventricular; $\mathrm{TI} A=$ transitory ischemic attack; $A A D=$ antiarrhythmic drug.

Definitions. Diagnosis of typical AFL was established based on the characteristic electrocardiographic (ECG) pattern with negative $P$-waves in the inferior leads and positive P-waves in lead $V_{1}$ (Figure 1). ${ }^{5}$ Amplitude of the
P-wave was determined by reading a standard 12-lead ECG with a typical AFL. The P-wave amplitude was measured from nadir to peak of the P-wave in inferior leads with standard ECG calibration at $10 \mathrm{~mm} / \mathrm{mV}$ and speed of $25 \mathrm{~mm} / \mathrm{s} .{ }^{6} \mathrm{AFL}$ was classified as paroxysmal or persistent if the AFL episode lasted $<7$ days or $\geq 7$ days, respectively ${ }^{1}$. Heart failure was defined as the presence of $\geq 2$ of the following criteria: (1) left ventricular systolic dysfunction (ejection fraction $<55 \%$ ), (2) functional New York Heart Association (NYHA) class $\geq 2$, (3) history of congestive heart failure before the procedure and (4) the administration of drug therapy for chronic heart failure $^{7}$. Hyperlipoproteinemia (HLP) was diagnosed if abnormally elevated blood levels of any or all lipids were found (i.e. total cholesterol $>5.2 \mathrm{mmol} / \mathrm{L}$ and triglicerides $>2.2 \mathrm{mmol} / \mathrm{L}$ ). Administration of general analge$\mathrm{sia} /$ sedation with midazolam, fentanyl and/or propofol was carried out during the procedure under the supervision of an anesthesiologist.

Ablation procedure. During all of the procedures noninvasive measurement of arterial blood pressure was performed every five minutes along with continuous noninvasive monitoring of pulse oximetry. Ablation of typical atrial flutter was described in details elsewhere. ${ }^{8}$ Via the right femoral vein and under the guidance of fluoroscopy, diagnostic quadripolar catheter was inserted into the distal coronary sinus (CS), duodecapolar (HALO-like) catheter was positioned on inferolateral right atrial wall and 3.5-4 mm irrigated-tip ablation catheter was positioned at cavo-tricuspid isthmus. Linear ablation of isthmus consisted of point by point RF applications during pull-back of the ablation catheter from the right ventricle toward the inferior vena cava. At each site RF delivery lasted from 40 sec to 120 sec or until the local atrial electrogram amplitude reduction of $>80 \%$. Ablation started at central isthmus (i.e. at $18 \mathrm{~h}$ in left oblique anterior projection) and, if needed, it was continued at septal and/or lateral isthmus until AFL termination and isthmus-block were achieved (Figure 2A). Ablation was performed in the temperature mode with

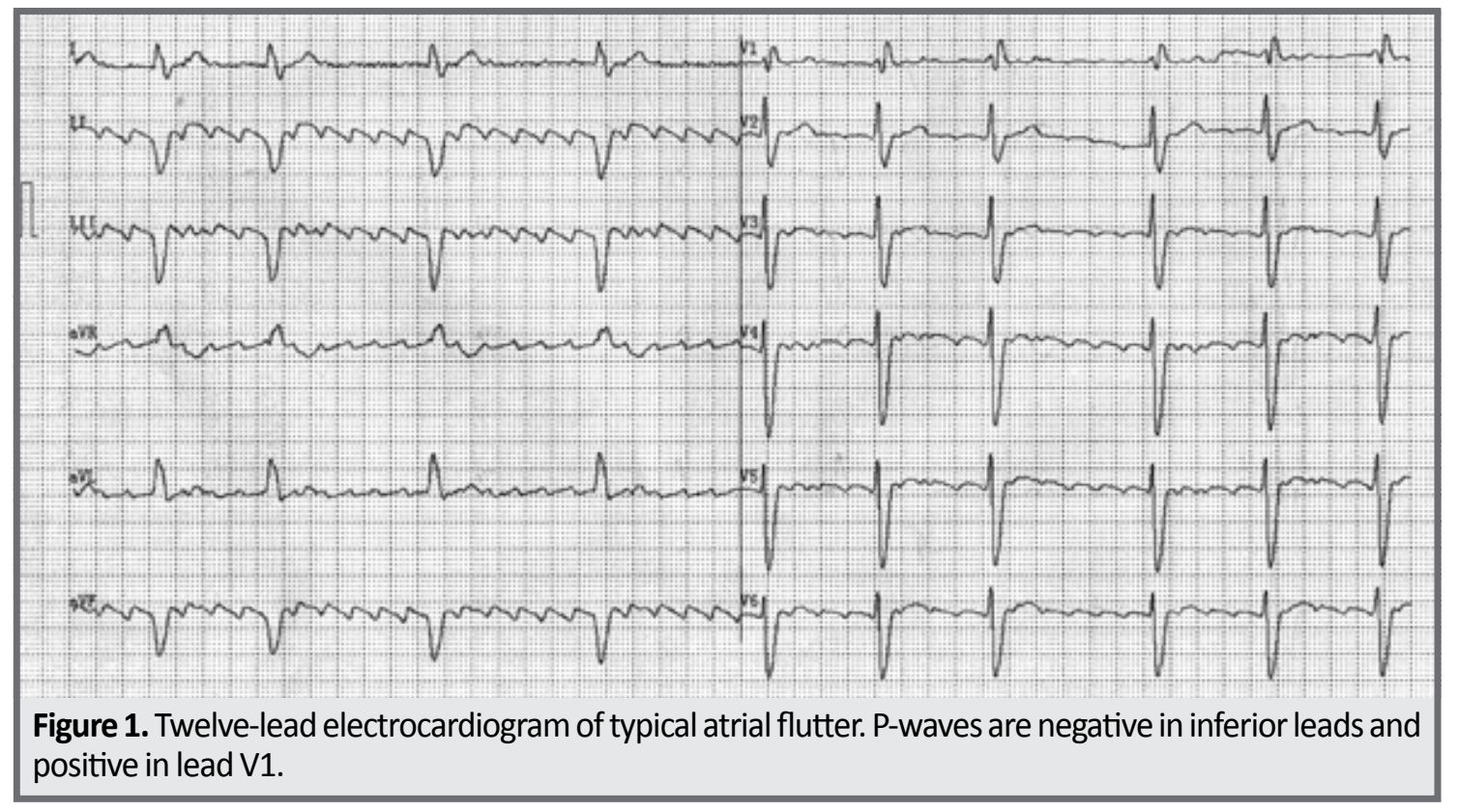




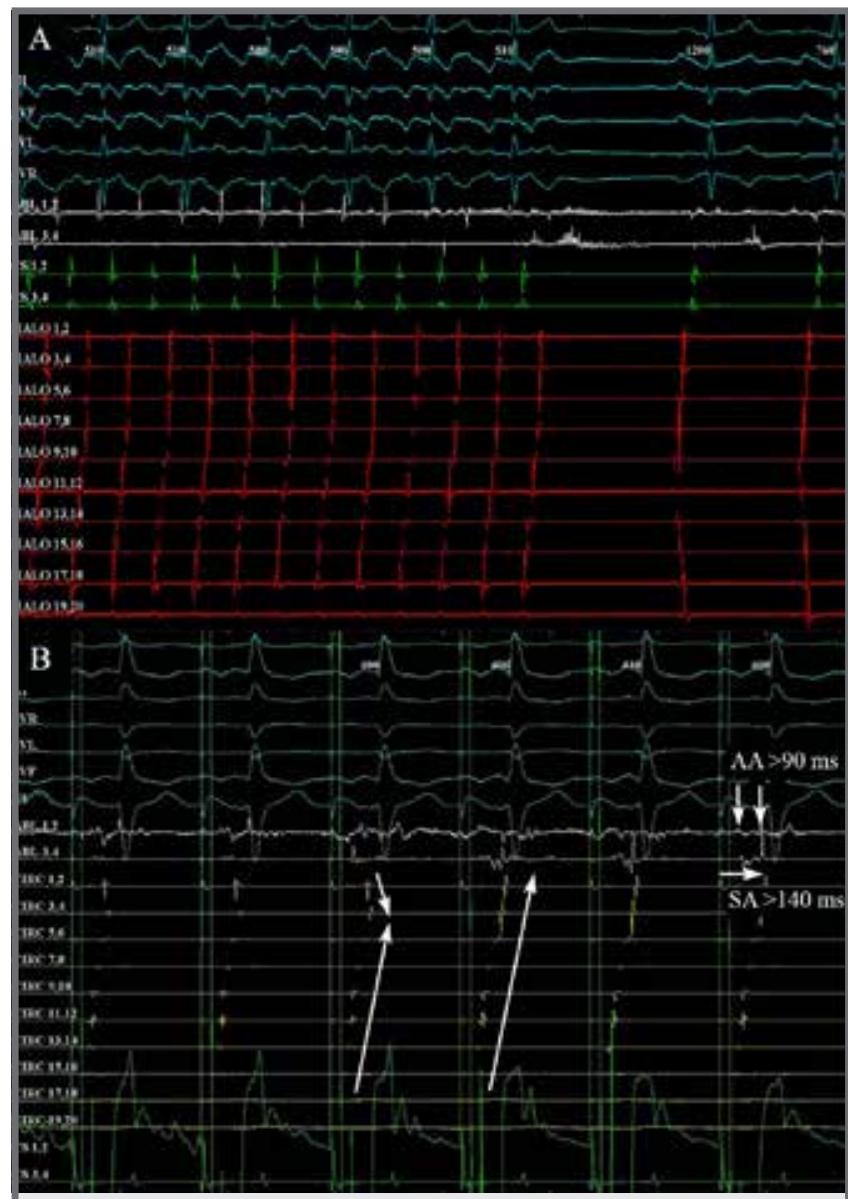

Figure 2. Termination of typical atrial flutter during radiofrequency ablation of cavotricuspid isthmus (A). Ablation was continued until isthmus block was achieved (B), confirmed by abrupt atrial activation sequence change and occurrence of widely spaced doubled atrial signals ( $A A>90 \mathrm{~ms}$ ) and prolongation of stimulus-toatrial potential (SA) interval (>140 ms).

the set-up of $43^{\circ} \mathrm{C}$ and $30-50 \mathrm{~W}$ (the irrigation flow rate was $17 \mathrm{~mL} / \mathrm{min}$ for applications $\leq 30 \mathrm{~W}$ and $25-30 \mathrm{~mL}$ / min for applications of $>30 \mathrm{~W}$ ). RF delivery was immediately terminated in the case of any increase in impedance, or its decrease by $>10-15 \Omega$. The criteria used to identify isthmus-block were: (1) craniocaudal atrial activation sequence along the duodecapolar catheter during CS pacing, (2) interval across the isthmus of $\geq 140 \mathrm{~ms}$, and (3) corridor of widely separated (doubled) atrial potentials $\geq 90$ ms along the entire ablation line (Figure 2B) ${ }^{3}$. After the last RF application the patient was monitored for 30 minutes before sheaths removal, and in the case of acute isthmus re-conduction, additional RF ablation was applied until stable conduction block across the isthmus was confirmed.

Anticoagulation. Unfractionated heparin was administered intravenously during persistent AFL ablation (bolus of 5000 i.u.). In all patients receiving oral anticoagulant therapy before procedure, the strategy of interrupted warfarin and bridging with subcutaneous low weight molecular heparin was applied. The procedure was performed when INR was below 1.5. Four hours after hemostasis, subcutaneous heparin was reintroduced, which was also done the following day with the oral anticoagu- lant, with bridging until the International Normalized Ratio (INR) reached the value of $\geq 2$. Postoperatively, the oral anticoagulation therapy was prescribed to all patients for 1 month after the ablation and thereafter only to patients with $\mathrm{CHADS}_{2}$ score of $\geq 2$.

Follow-up after ablation. After the procedure, all patients were followed in the outpatient clinic with regular ECG examinations at 1, 3, 6 and 12 months after the procedure, and subsequently once per year. In symptomatic patients every effort was made to identify the potential AFL recurrence. In these patients 24-48h Holter-monitoring was performed or the patients were admitted to hospital for additional heart rhythm monitoring. ${ }^{1,5}$

Statistical analysis. Continuous variables are presented as mean $( \pm 1 S D)$ and categorical variables are summarized as percentages. The association of clinical and procedural variables presented in Table 2 with the AFL recurrence after the ablation was analysed using univariate and multivariable Cox proportional hazards model. The actuarial probability of freedom from AFL after isthmus ablation was calculated and graphically presented with the method of Kaplan and Meier. Differences between the curves were tested for significance by the log rank statistic.

The value of $p<0.05$ was considered to be statistically significant. Statistical analysis was performed with the SPSS software, version 18.0.

\section{Results}

The study group consisted of 248 patients (the mean age was $57.4 \pm 11.6$ years and 180 [72.6\%] were male). Baseline patients' characteristics are presented in detail in Table 1. Structural heart disease and co-morbidities were diagnosed in 139 (56.0\%) and 193 (77.8\%) patients, respectively. Associated atrial fibrillation was documented in 110 (44.4\%) patients and heart failure in 89 (35.9\%) patients.

Total of 248 patients underwent 303 AFL ablation procedures. Fifthy five redo procedures were performed in 45 patients ( 1 to 4 times per patient). Primary success rate of the first and repeated procedure was $83.1 \%$ and $92.7 \%(p=0.095)$. The mean number of RF applications was significantly higher $(23.1 \pm 14.5$ vs. $18.5 \pm 11.6$, $\mathrm{p}=0.013)$, and RF time $(20.8 \pm 12.6 \mathrm{~min}$ vs. $16.0 \pm 9.7 \mathrm{~min}$, $\mathrm{p}=0.002)$ as well as fluoroscopy time (15.9 $\pm 9.4 \mathrm{~min}$ vs. $12.2 \pm 7.0 \mathrm{~min}, \mathrm{p}=0.002$ ) were significantly longer in the first compared to redo ablation. Major complications were registered in $1.7 \%$ (5/303) of procedures, including: two cases of hemodynamically stable pericardial effusion treated conservatively, two complications at vascular access site (one arteriovenous fistula surgically treated and one large groin hematoma that required blood transfusion) and one high grade AV block in patient with already implanted biventricular pacemaker.

During the mean follow-up time of $17.6 \pm 14.7$ months, $22.6 \%$ of patients $(56 / 248)$ had AFL recurrence following the first procedure, but after the last ablation, recurrence of AFL was recorded in only $5.7 \%$ of patients (14/248). Recurrences of paroxysmal AFL and persistent AFL were recorded in 28 (50.0\%) and 28 (50.0\%) patients after the first ablation, and in 10 (71.4\%) and 4 
Table 2. Univariate and multivariable analysis of potential predictors of AFL recurrence after ablation

\begin{tabular}{|c|c|c|c|c|c|c|}
\hline & \multirow{2}{*}{$\begin{array}{l}\text { Procedures } \\
\text { with } \\
\text { AFL recurrence } \\
(n=66)\end{array}$} & \multirow{2}{*}{$\begin{array}{l}\text { Procedures } \\
\text { without } \\
\text { AFL recurrence } \\
(n=237)\end{array}$} & \multicolumn{2}{|l|}{ Univariate analysis } & \multicolumn{2}{|c|}{ Multivariable analysis } \\
\hline & & & HR $(95 \% \mathrm{Cl})$ & P-value & HR $(95 \% \mathrm{Cl})$ & P-value \\
\hline Age (years) & $51.1 \pm 12.1$ & $59.5 \pm 10.0$ & $0.97(0.95-0.99)$ & 0.001 & $0.95(0.93-0.98)$ & $<0.001$ \\
\hline Male gender & $48(72.7 \%)$ & $176(74.3 \%)$ & $1.03(0.60-1.78)$ & 0.907 & - & - \\
\hline $\mathrm{BMI}\left(\mathrm{kg} / \mathrm{m}^{2}\right)$ & $26.9 \pm 4.2$ & $28.1 \pm 4.6$ & $0.97(0.91-1.03)$ & 0.286 & - & - \\
\hline Paroxysmal AFL & $27(40.9 \%)$ & 78 (32.9 \%) & $1.29(0.79-2.10)$ & 0.306 & - & - \\
\hline AF before AFL abl. & $34(51.5 \%)$ & $102(43.0 \%)$ & $1.31(0.81-2.12)$ & 0.279 & - & - \\
\hline P-wave amplitude (mA) & $2.4 \pm 0.9$ & $2.2 \pm 0.7$ & $1.38(1.00-1.90)$ & 0.049 & - & - \\
\hline $\mathrm{CHADS}_{2}$ scor & $1.1 \pm 0.9$ & $1.4 \pm 1.0$ & $0.77(0.56-1.03)$ & 0.073 & - & - \\
\hline Left ventricular EF (\%) & $54.6 \pm 13.4$ & $53.3 \pm 13.6$ & $1.01(0.84-1.22)$ & 0.929 & - & - \\
\hline LA diameter (mm) & $40.4 \pm 5.2$ & $43.9 \pm 5.7$ & $0.95(0.91-1.00)$ & 0.040 & - & - \\
\hline Heart failure & $21(31.8 \%)$ & $86(36.2 \%)$ & $0.90(0.54-1.51)$ & 0.688 & - & - \\
\hline Structural heart disease & $36(54.5 \%)$ & $137(57.8 \%)$ & $0.86(0.53-1.40)$ & 0.547 & - & - \\
\hline Dilated cardiomyopathy & $24(36.3 \%)$ & $91(38.4 \%)$ & $1.05(0.63-1.75)$ & 0.860 & - & - \\
\hline Coronary artery disease & $11(16.7 \%)$ & $49(20.7 \%)$ & $0.92(0.48-1.76)$ & 0.808 & - & - \\
\hline Congenital heart disease & $11(16.7 \%)$ & $23(9.7 \%)$ & $1.25(0.66-2.40)$ & 0.494 & - & - \\
\hline Valvular heart disease & $5(7.6 \%)$ & $18(7.6 \%)$ & $0.99(0.40-2.46)$ & 0.979 & - & - \\
\hline Comorbidities & 46 (69.7 \%) & $184(77.6 \%)$ & $0.88(0.52-1.49)$ & 0.634 & - & - \\
\hline Hypertension & $30(45.4 \%)$ & $142(59.9 \%)$ & $0.70(0.43-1.14)$ & 0.154 & - & - \\
\hline Diabetes mellitus & $3(4.5 \%)$ & $32(13.5 \%)$ & $0.39(0.12-1.23)$ & 0.109 & - & - \\
\hline COPD & $2(3.0 \%)$ & $15(6.3 \%)$ & $0.74(0.18-3.04)$ & 0.677 & - & - \\
\hline Chronic renal failure & $1(1.5 \%)$ & $25(10.5 \%)$ & $0.18(0.03-1.30)$ & 0.089 & - & - \\
\hline Hyperlipoproteinemia & $34(51.5 \%)$ & $98(41.3 \%)$ & $1.69(1.04-2.74)$ & 0.034 & $2.00(1.00-3.99)$ & 0.049 \\
\hline Redo procedure & $10(15.1 \%)$ & $45(19.0 \%)$ & $0.64(0.33-1.26)$ & 0.194 & - & - \\
\hline General analgosedation & $5(7.6 \%)$ & $46(19.4 \%)$ & $0.38(0.15-0.94)$ & 0.036 & - & - \\
\hline RF energy output $\leq 35 \mathrm{~W}$ & $16(24.2 \%)$ & 75 (31.6 \%) & $0.80(0.45-1.40)$ & 0.426 & - & - \\
\hline $\begin{array}{l}\text { Operator's expirience }>100 \\
\text { abl. }\end{array}$ & $29(43.9 \%)$ & $174(73.4 \%)$ & $0.56(0.34-0.92)$ & 0.022 & - & - \\
\hline Number of RF pulses (n) & $25.1 \pm 17.2$ & $21.1 \pm 12.4$ & $1.02(1.00-1.03)$ & 0.069 & - & - \\
\hline Isthmus block achieved & $43(65.2 \%)$ & $214(90.3 \%)$ & $0.25(0.15-0.42)$ & $<0.001$ & $0.22(0.10-0.46)$ & $<0.001$ \\
\hline Fluoroscopy time (min) & $16.4 \pm 9.1$ & $13.1 \pm 7.7$ & $1.04(1,01-1.07)$ & 0.006 & - & - \\
\hline RAAS blockers after procedure & $29(43.9 \%)$ & $145(61.2 \%)$ & $0.62(0.38-1.00)$ & 0.051 & - & - \\
\hline Statins after procedure & $23(34.8 \%)$ & $83(35.0 \%)$ & $1.24(0.75-2.05)$ & 0.409 & - & - \\
\hline
\end{tabular}

Data presented as mean \pm SD or numbers with percentages.

$\mathrm{AFL}=$ atrial flutter; $\mathrm{BMI}=$ body mass index; $\mathrm{AF}=$ atrial fibrillation; $\mathrm{EF}=$ ejection fraction; $\mathrm{LA}=$ left atrium; $\mathrm{COPD}=$ chronic obstructive pulmonary disease; RF=radiofrequency; RAAS=renin-angiotensine-aldosterone system.

patients (28.6\%) after the last ablation, respectively. In Figure 3, Kaplan-Meyer curves show significant difference in the AFL recurrence after the first and the last ablation procedure $(\log \operatorname{rank} p<0.001)$.

The mean time from ablation to AFL recurrence was $8.1 \pm 6.4$ months; the shortest time to recurrence was 1 day and the longest time was 33 months. The vast majority of recurrences of arrhythmia (48/66, 72.7\%) occurred in the first year after ablation, the recurrence rate was low during further follow-up to the end of the study (Figure 4). On univariate analysis (Table 2), the recurrence of AFL was significantly more frequent in younger patients, higher AFL P-wave amplitude on standard ECG, HLP, smaller left atrium size, longer fluoroscopy time, and significantly less frequent in in case the stable isthmus block has been achieved during ablation $(p<0.001)$, with procedures performed by operator with experience of $>100$ AFL ablations and with procedures performed under general analgosedation of the patient. Multivariable analysis showed that patient age (Hazard Ratio [HR] 0.95; $95 \%$ Confidence Interval $[\mathrm{Cl}], 0.93-0.98, p<0.001)$, stable isthmus block at the end of procedure (HR: $0.22 ; 95 \%$ $\mathrm{Cl}, 0.10-0.46, p<0.001$ ) and HLP diagnosis (HR 2.00; 95\% $\mathrm{Cl}, 1.00-2.99, \mathrm{p}=0.049$ ) were independently associated with postprocedural recurrence of AFL (Table 2). Using ROC analysis the age of 56.5 years was determined as a cutt-off value that best discriminated patients with and without AFL recurrence after ablation (area under curve: $0.33 ; 95 \% \mathrm{Cl}, 0.26-0.40, p<0.001$ ). Figure 5 displays Kaplan-Meier analysis of AFL recurrence-free rate in patients of $<56.5$ years and $\geq 56.5$ years at procedure and Figure 6 the cumulative probability of freedom from AFL 


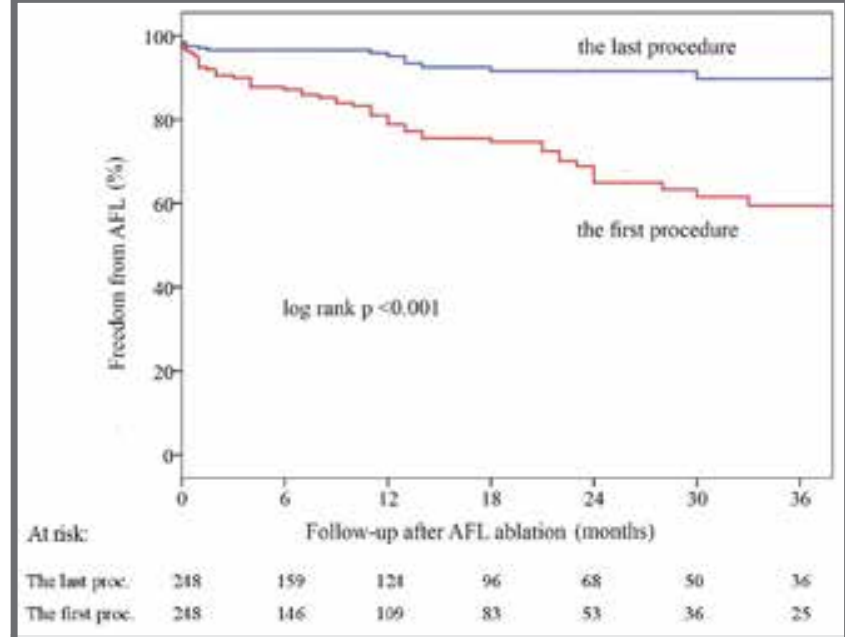

Figure 3. Kaplan-Meier estimates of atrial flutter recurrence after the first and after the last ablation. Outcome after the last procedure was significantly better than after the first procedure (log rank $p<0.001)$.

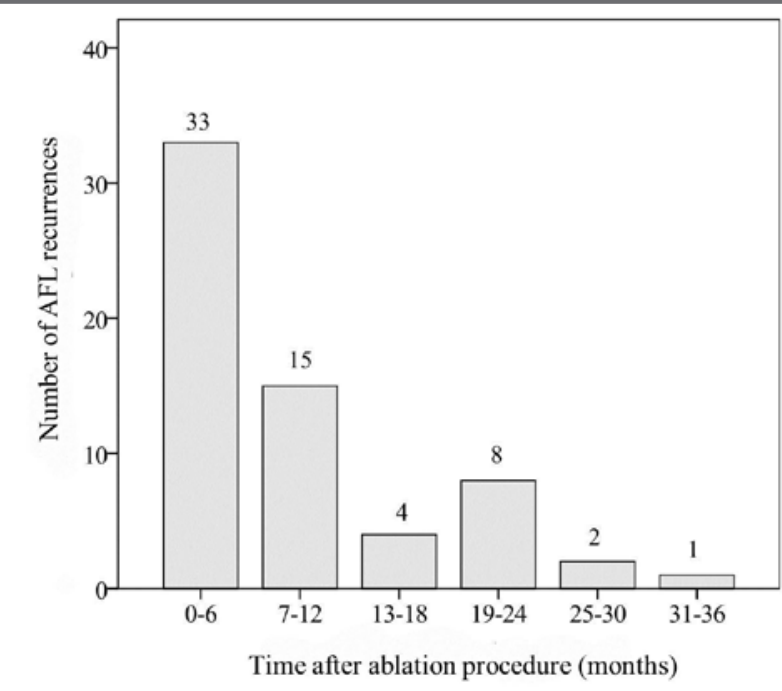

Figure 4. Time frame of AFL recurrences during the follow-up after isthmus ablation.

following ablation procedures completed with and without stable isthmus-block. Figure 7 shows the freedom from AFL after ablation procedure in patients with or without hyperliporpoteinemia.

During the follow-up after AFL ablation, atrial fibrillation was recorded in $31.0 \%(77 / 248)$ of patients and 199 (80.2\%) patients were on antiarrhythmic drugs (41.9\% patients were on amiodaron).

\section{Discussion}

The main finding of our study were: (1) majority of AFL recurrences were recorded during the first 6-12 months after ablation, and (2) variables such as (in)complete isthmus ablation, hyperlipoproteinemia and younger patient age were independently associated with recurrence of AFL after procedure.

Mechanism and time frame of AFL recurrence after ablation. Recent meta-analysis, including almost 10.000 patients undergoing irrigated RF ablation of AFL, dem-

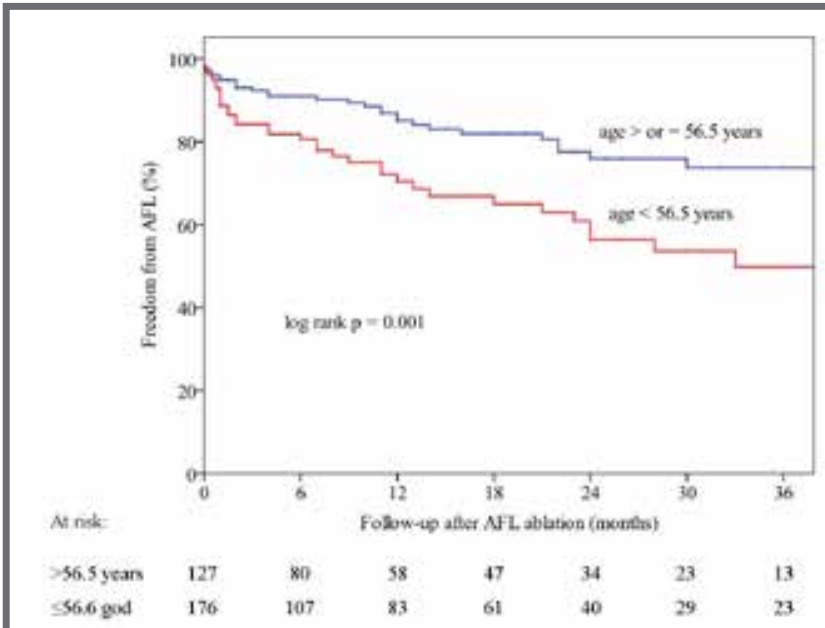

Figure 5. Kaplan-Meier curves showing significantly less frequent atrial flutter recurrence rate in patients $<56.5$ years compared to patients $\geq 56.5$ years.

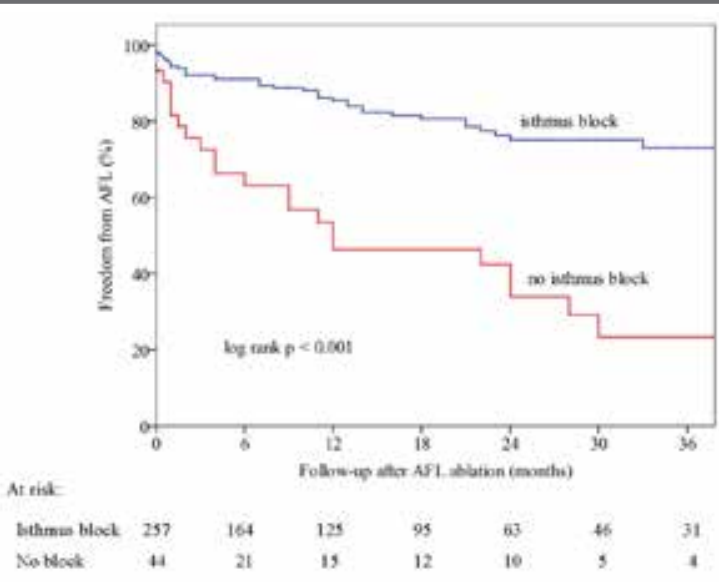

Figure 6. Cumulative recurrence rate of atrial flutter after procedures completed with isthmus block and with only partial isthmus ablation.

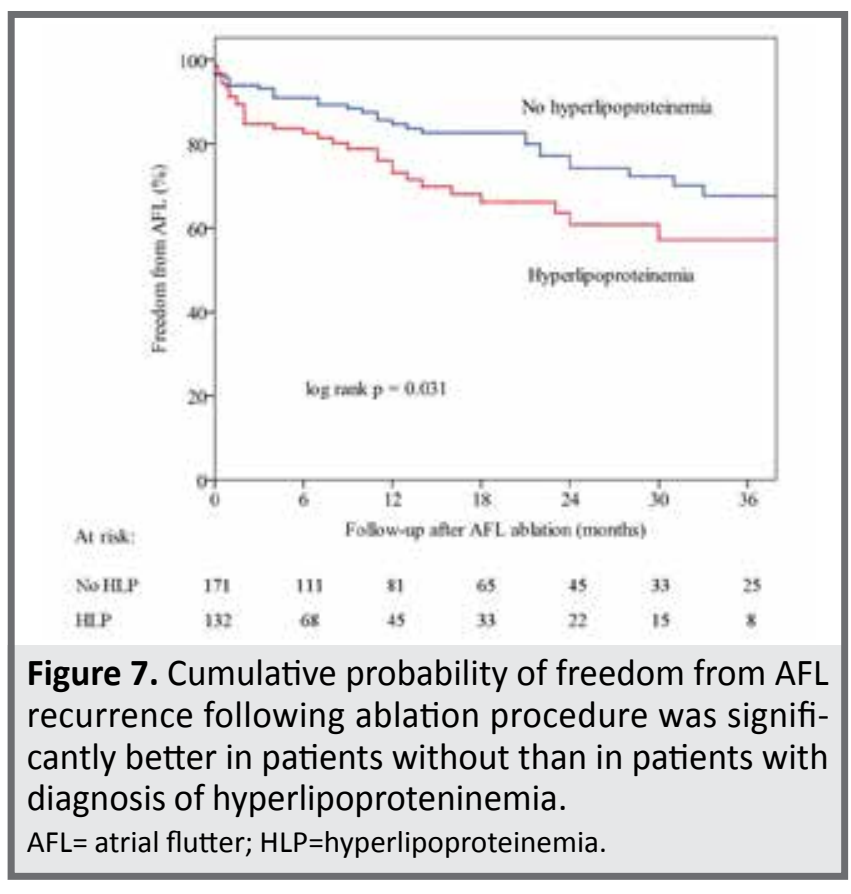


onstrated the AFL recurrence rate of $11 \%{ }^{4}$. The recurrence rate in our study was twice as high, probably due to the learning curve during the introduction of the irrigated RF technology in our center. ${ }^{9}$ However, after the last procedure AFL recurrence was observed in only $5.7 \%$ of our patients.

No significant increase in the rate of AFL recurrence was recorded after 6 months following isthmus ablation. ${ }^{4}$ In fact, after isthmus ablation, AFL recurrence rate in studies with different follow-up period was constant. Thus the incidence of recurrence with a follow-up of 6 months was 9.8\%, 12 months $14.5 \%, 24$ months $11.1 \%, 36$ months $10.6 \%$ and $>36$ months $14.6 \% .^{4}$ In one study with a minimum follow-up of 3 years after the procedure, $73 \%$ of all AFL recurrences was registered in the first 6 months after ablation, while the remaining $27 \%$ of recurrences was observed over a period of 6 months to 2 years after the procedure. ${ }^{10}$ Our results are in line with these findings. This is in contrast with the finding of progressive and cumulative increase in the rate of AF recurrence after ablation of AF by about $10 \%$ annually in the first five years after the procedure. ${ }^{11}$

Atrial flutter is macroreentrant atrial tachycardia, depending on a clearly defined anatomical substrate, i.e. cavotricuspid isthmus. ${ }^{1,5}$ Therefore it is expected that complete isthmus ablation will lead to permanent elimination of the arrhythmia. Incomplete ablation of isthmus or postprocedural recovery of trans-isthmus conduction due to edema resolution may be responsible for clinical AFL recurrence. ${ }^{12,13}$ However, the mechanism and the substrate of AF are much more complex, and $A F$ ablation strategy is largely based just on isolation of AF triggers from the pulmonary veins. ${ }^{14}$ The presence of associated comorbidities such as aging, hypertension, diabetes etc. may lead to the subsequent evolution of the AF substrate after ablation, increasing the risk of arrhythmia recurrence. ${ }^{14}$

Risk factors for AFL recurrence. In our study, AFL recurrence after ablation was significantly more frequent with younger age, higher P-wave amplutude of AFL on standard ECG, smaller left atrium size and HLP, while the recurrences of AFL were less frequent if the procedure was performed under general analgosedation and by more expirienced operators, with ablations completed with isthmus-block and procedures with shorter fluoroscopic time. The independent predictors of AFL recurrence after ablation were younger patient age, HLP and incomplete isthmus ablation. Other studies have identified the complex isthmus anatomy (i.e. prominent Eustachian ridge), dilated right atrium, prolonged procedural and fluoroscopic time and incomplete isthmus ablation as potential predictors for AFL recurrence. ${ }^{12,13,15}$

Bidirectional isthmus block represents and EP surrogate of its transmural necrotic lesion. ${ }^{3}$ Clinical recurrences of AFL were significantly less frequent in recent studies in which the ablation endpoint was isthmusblock, compared to historical studies where the endpoint was only AFL noninducibility after isthmus ablation ( $7 \%$ vs $26 \%$ ). ${ }^{4,13}$

It has been already recognized by other authors that the patient age may affect the risk of arrhythmia recur- rence after successful RF ablation of certain arrhythmogenic substrates. ${ }^{16,17}$ The patients with atrioventricular nodal reentrant tachycardia recurrence after slow pathway ablation were significanly younger compared with patients without tachycardia recurrence (43.8 \pm 16.9 yeras. vs. $53.0 \pm 15.2$ years). ${ }^{16}$ In addition, after typical AFL ablation, recurrence rate was significantly higher in patients aged $<70$ years than in older patients $(9.0 \%$ vs. $14.8 \%) .{ }^{17}$ It was suggested that younger patients may have a greater capacity for tissue regeneration after thermally-mediated RF ablation. In addition, it is possible that the operator uses less aggressive approach for ablation of the substrate in younger patients, in order to avoid complications. ${ }^{16}$ Our study confirmed these findings. We identified the age of $<56.5$ years as the value that best differentiate patients at high risk for AFL recurrence after ablation.

The causes of higher AFL recurrence rate after ablation in patients with HLP in our study are not clear. AFL and $A F$ are related arrhythmias and often coexist in the same patient. ${ }^{1,5}$ It has been shown that AF often appears as a transitional tachyarrhythmia shortly before the organization to typical AFL. ${ }^{18}$ Patients with metabolic syndrome (central obesity, hypertension, dyslipidemia and impaired glucose tolerance) compared to those without the syndrome have an increased risk of AF recurrence after left atrial ablation procedure. ${ }^{19}$ The complex interplay between the inflammation, collagen deposition in the myocardium and abnormal fatty acid metabolism could be responsible for the evolution of substrate that favors the development of atrial tachyarrhythmias in patients with dyslipidemia. ${ }^{20}$

\section{Conclusion}

Incidence of AFL recurrence after the first RF-CA of cavo-tricuspid isthmus in our study was around $20 \%$. However, after the last procedure it was observed in less than $6 \%$ of our patients. Clinical recurrences of AFL mostly occur in the first 6-12 months after the procedure, although very late recurences are possible. The independent predictors of AFL recurrence after ablation were younger patient age, diagnosis of HLP and incomplete ablation of isthmus.

\section{References}

1. Camm AJ, Lip GY, De Caterina R, et al. 2012 focused update of the ESC Guidelines for the management of atrial fibrillation: an update of the 2010 ESC Guidelines for the management of atrial fibrillation-developed with the special contribution of the European Heart Rhythm Association. Europace 2012;14:1385-1413.

2. Pérez J, Schubert CM, Parvez B, Pathak V, Ellenbogen KA, Wood MA. Long-term outcomes after catheter ablation of cavo-tricuspid isthmus dependent atrial flutter: a meta-analysis. Circ Arrhythm Electrophysiol 2009;2:393-401.

3. Schwartzman D, Callans D, Gottlieb C, Dillon S, Movsowitz C, Marchlinski F. Conduction block in the inferior vena caval-tricuspid valve isthmus: association with outcome of radiofrequency ablation of typ I atrial flutter. J Am Coll Cardiol 1996;28:1519-1531.

4. Natale A, Newby KH, Pisano E, et al. Prospective randomized comparison of antiarrhythmic therapy versus first-line radiofrequency ablation in patients with atrial flutter. J Am Coll Cardiol 2000;35:1898-1904. 
5. Calkins H, Kuck KH, Cappato R, et al. 2012 HRS/EHRA/ECAS expert consensus statement on catheter and surgical ablation of atrial fibrillation: recommendations for patient selection, procedural techniques, patient management and follow-up, definitions, endpoints, and research trial design: a report of the Heart Rhythm Society (HRS) Task Force on Catheter and Surgical Ablation of Atrial Fibrillation. Developed in partnership with the European Heart Rhythm Association (EHRA), a registered branch of the European Society of Cardiology (ESC) and the European Cardiac Arrhythmia Society (ECAS); and in collaboration with the American College of Cardiology (ACC), American Heart Association (AHA), the Asia Pacific Heart Rhythm Society (APHRS), and the Society of Thoracic Surgeons (STS). Endorsed by the governing bodies of the American College of Cardiology Foundation, the American Heart Association, the European Cardiac Arrhythmia Society, the European Heart Rhythm Association, the Society of Thoracic Surgeons, the Asia Pacific Heart Rhythm Society, and the Heart Rhythm Society. Heart Rhythm 2012;9:632-696.

6. Rotter M, Scavee C, Sacher F, et al. Correlation of atrial electrocardiographic amplitude with radiofrequency energy required to ablate cavotrcuspid isthmus-dependent atrial flutter. Heart Rhythm 2005;2:263-269.

7. Poci D, Backman L, Karlsson T, Edvardsson N. New or aggravated heart failure during long-term right ventricular pacing after AV junctional catheter ablation. Pacing Clin Electrophysiol 2009;32:2009-2016.

8. Jais $P$, Hocini M, Gillet $T$, Shah $D$, et al. Effectiveness of irrigated tip catheter ablation of common atrial flutter. Am J Cardiol 2001;88:433-435.

9. Sairaku A, Nakano Y, Oda N, et al. Learning curve for ablation of atrial fibrillation in medium-volume centers. J Cardiol 2011;57:263-268.

10. Ellis ER, Josephson ME. Heart failure and tachycardia-induced cardiomyopathy. Curr Heart Fail Rep 2013;10:296-306.
11. Bertaglia E, Tondo C, De Simone A,et al. Does catheter ablation cure atrial fibrillation? Single-procedure outcome of drug-refractory atrial fibrillation ablation: a 6-year multicentre experience. Europace 2010;12:181-187.

12. Hsieh MH, Tai CT, Chiang CE, et al. Recurrent atrial flutter and atrial fibrillation after catheter ablation of the cavotricuspid isthmus: a very long-term follow-up of 333 patients. J Interv Card Electrophysiol 2002;7:225-231.

13. Schmieder S, Ndrepepa G, Dong J, et al. Acute and long-term results of radiofrequency ablation of common atrial flutter and the influence of the right atrial isthmus ablation on the occurrence of atrial fibrillation. Eur Heart J 2003;24:956-962.

14. Mujović NM, Marinković MM, Potpara TS, Geller L. Catheter ablation of lone atrial fibrillation. Curr Pharm Des 2015;21:591-612.

15. Asirvatham S. Correlative anatomy and electrophysiology for the interventional electrophysiologist: right atrial flutter. J Cardiovasc Electrophysiol 2009;20:113-122.

16. Estner HL, Ndrepepa G, Dong J, et al. Acute and long-termresults of slow pathway ablation in patients with atrioventricular nodal reentrant tachycardia - an analysis of the predictive factors for arrhythmia recurrence. Pacing Clin Electrophysiol 2005;28:102-110.

17. Brembilla-Perrot B, Sellai JM, et al. Risk and outcome after ablation of isthmus-dependent atrial flutter in elderly patients. PloS One 2015;10:e0127672.

18. Loutrianakis E, Barakat T, Olshansky. Early versus late atrial fibrillation after atrial flutter ablation. J Interv Card Electrophysiol 2002;6:173-180.

19. Lin KJ, Cho SI, Tiwari N, et al. Impact of metabolic syndrome on the risk of atrial fibrillation recurrence after catheter ablation: systematic review and meta-analysis. J Interv Card Electrophysiol 2014;39:211-223.

20. Shah AN, Mittal S, Sichrovsky TC, et al. Long-term outcome following successful pulmonary vein isolation: pattern and prediction of very late recurrence. J Cardiovasc Electrophysiol 2008;19:661-667

\title{
Sažetak
}

\section{Prediktori recidiva tipičnog atrijalnog flatera nakon radiofrekventne ablacije kavotrikuspidnog istmusa upotrebom katetera sa spoljnom irigacijom}

\author{
Nebojša Mujovići, ${ }^{1,2}$ Milan Marinković1 ${ }^{1}$ Nebojša Marković ${ }^{1}$, Tatjana S. Potpara ${ }^{1,2}$ \\ ${ }^{1}$ Klinika za kardiologiju, Klinički centar Srbije, Višegradska 26, Beograd, Srbija; ${ }^{2}$ Medicinski fakultet, Univerzitet u Beogradu, Dr Subotića 8 , \\ Beograd, Srbija.
}

Uvod: identifikacija faktora rizika za pojavu recidiva atrijalnog flatera (R-AFL) nakon radiofrekventne (RF) kateter-ablacije (KA) može omogućiti bolju selekciju bolesnika za invazivno lečenje kao i optimalnu terapiju posle procedure. Ispitivali smo incidencu, vreme pojave R-AFL i prediktore pojave R-AFL posle KA.

Metod: Retrospektivno smo analizirali bolesnike koji su tokom 7-godišnjeg perioda bili podvrgnuti KA tipičnog AFL primenom RF struje sa spoljašnjom irigacijom i kod kojih je blok u istmusu bio krajnji cilj procedure.

Rezultati: Kod ukupno 248 bolesnika (prosečna starost $57.4 \pm 11.6$ god., 72.6\% muškarci) izvedene su 303 procedure KA. Kod 45 bolesnika procedura je bila ponovljena (1-4 puta). KA istmusa je bila primarno uspešna u 87\% procedura. Tokom praćenja

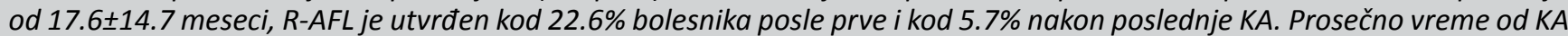
do R-AFL bilo je $8.1 \pm 6.4$ meseci (od 1 dana do 33 meseca). Većina R-AFL (72.7\%) javila se tokom prve godine posle KA. Univarijantnom analizom utvrđena je značajna povezanost $R$-AFL sa životnim dobom, amplitudom P-talasa, hiperlipidemijom, dijametrom leve pretkomore, vremenom fluoroskopije, postizanjem bloka u istmusu, upotrebom analgosedacije i operatorovim iskustvom. Multivarijantnom analizom su kao nezavisni prediktori R-AFL identifikovani životno doba (HR: 0.95), stabilan blok u istmusu (HR: 0.22) i hiperlipidemija (HR: 2.00).

Zaključak: Konačna stopa R-AFL nakon poslednje RF-KA iznosila je oko 6\%, s tim da je procedura bila ponovljena kod svakog petog bolesnika. R-AFL su najčešće utvrđeni tokom prve godine posle procedure. Prediktori R-AFL posle RF-KA bili su mlađe životno doba, hiperlipidemija i nepotpuna ablacija istmusa.

Ključne reči: atrijalni flater; kateter-ablacija; kavotrikuspidni istmus; recidiv posle ablacije. 